\title{
MANAGEMENT of E-WASTE DISPOSAL
}

\author{
Mridula Verma \\ Associate Professor, Department of Chemistry, M.M.H College, Ghaziabad, India
}

\begin{abstract}
E-waste' means electrical and electronic equipment, whole or in part discarded as waste by the consumer or bulk consumer as well as rejects from manufacturing, refurbishment and repair processes. It contains many hazardous substances, such as halogenated compounds, heavy metals, lead, cadmium, mercury and micro and nano-size dusts, all of which require proper handling during the storage, collection, recycling and disposal stages. Major recycling of ewaste is carried out in the non-formal sector using primitive and hazardous methods. Adequate legislative measures and cost-effective, environmental friendly, technological solution would be needed to address the issue. The E-Waste (Management) Rules, 2016 have to be followed for the safe disposal of E-wastes.
\end{abstract}

Keywords: E-waste, recycle, extended producer responsibility, equipments, waste management

\section{INTRODUCTION}

E-Waste (Management) Rules, 2016 shall apply to every manufacturer, producer, consumer, bulk consumer, collection centers, dealers, e-retailer, refurbisher, dismantler and recycler involved in manufacture, sale, transfer, purchase, collection, storage and processing of e-waste or electrical and electronic equipment including their components, consumables, parts and spares which make the product operational. The end of life and discarded electronics products ranging from computers, equipment used in Information and Communication Technology, home appliances, audio and video products and all of their peripherals are popularly known as E-waste. E-waste comprises of the relatively expensive and essentially durable products used for data processing, telecommunications or entertainment in private households and businesses. E-waste is not hazardous if it is stocked in safe storage or recycled by scientific methods or transported from one place to the other in parts or in totality in the formal sector. The e-waste can, however, be considered hazardous if recycled by primitive methods. E-waste contains several substances such as heavy metals, plastics, glass etc., which can be potentially toxic and hazardous to the environment and human health, if not handled in an environmentally sound manner. E-waste recycling in the non formal sector by primitive methods can damage the environment. The ill effects of e-waste could be on soil through leaching of hazardous contents from landfills; in water due to contamination of rivers, wells and other water sources; in air due to emission of gases and burning of e-waste. The recycling process, if not carried out properly, can cause damage to human being through inhalation of gases during recycling, contact of the skin of the workers with hazardous substances. The hazardous and toxic substances found in ewaste include lead and cadmium in printed circuit boards. Lead is primarily found in all electronic products/ assembly, cathode ray tubes etc. Polychlorinated biphenyls are found in capacitors and transformers. [1,2,3,4]

\section{PROCEDURE FOR SEEKING AND GRANT OF AUTHORISATION}

\section{A. EXTENDED PRODUCER RESPONSIBILITY - AUTHORISATION of PRODUCERS}

(a) Every producer of electrical and electronic equipment listed in Schedule I, shall make an application for Extended Producer Responsibility - Authorisation in Form-1 to Central Pollution Control Board.[1]

(b) On receipt of the application complete in all respects, the Central Pollution Control Board will carry out evaluation of the Extended Producer Responsibility Plan and on being satisfied that the producer has detailed out an effective system to manage Extended Producer Responsibility in the country, shall grant Extended Producer Responsibility Authorisation, in Form 1(aa) within a period of one hundred and twenty days. The Extended Producer Responsibility Authorisation shall be valid for a period of five years.[1]

(c) The Central Pollution Control Board after grant of Extended Producer Responsibility - Authorisation shall forward the Extended Producer Responsibility Plan to respective State Pollution Control Board for monitoring.

(d) The producer authorised under the provision of this rule shall maintain records in Form-2 and shall file annual returns of its activities of previous year in Form-3 to the Central Pollution Control Board on or before 30th day of June of every year.[1]

(e) In case of transfer or sale of assets by the producers the liability under Extended Producer Responsibility shall also be transferred to the buyer.[5]

(f) A Producer Responsibility Organisation shall apply to the Central Pollution Control Board for registration to undertake the activities prescribed for Producer Responsibility Organisations under these Rules.[5] 


\section{B. AUTHORISATION of MANUFACTURER}

(a) ) The manufacturer generating e-waste shall obtain an authorisation from the concerned State Pollution Control Board.

(b) The manufacturer shall make an application for authorisation, in Form 1(a) to the concerned State Pollution Control Board for grant of authorisation.

(c) On receipt of the application complete in all respects for the authorisation, the concerned State Pollution Control Board may, after such enquiry as it considers necessary and on being satisfied that the applicant possesses appropriate facilities, technical capabilities and equipment to handle e-waste safely, grant within a period of one hundred and twenty days an authorisation in Form 1(bb) to the applicant to carry out safe operations in the authorised place only, which shall be valid for a period of five years.[1]

(d) Every person authorised under these rules shall maintain the record of e-waste handled by them in Form-2 and prepare and submit to the concerned State Pollution Control Board, an annual return containing the details specified in Form 3 on or before the 30th day of June following the financial year to which that return relates. [1]

\section{PROCEDURE for GRANT of AUTHORISATION to DISMANTLER or RECYCLER}

(a) Every Dismantler or Recycler of e-waste shall make an application in Form-4 in triplicate to the concerned State Pollution Control Board accompanied with a copy of the following documents for the grant or renewal of authorisation. (1) Consent to establish granted by the concerned State Pollution Control Board under the Water (Prevention and Control of Pollution) Act, 1974, (25 of 1974) and the Air (Prevention and Control of Pollution) Act, 1981(21 of 1981). [1]

(2) Certificate of registration issued by the District Industries Centre or any other government agency authorised in this regard.

(3) Proof of installed capacity of plant and machinery issued by the District Industries Centre or any other government agency authorised in this behalf.

(b) The concerned State Pollution Control Board, on being satisfied that the application is complete in all respects and that the applicant is utilising environmentally sound technologies and possess adequate technical capabilities, requisite facilities and equipment to dismantle or recycle and process e-waste in compliance to the guidelines specified by Central Pollution Control Board from time to time and through site inspection, may grant authorisation to such applicants stipulating therein necessary conditions as deemed necessary for carrying out safe operations in the authorised place only.[1]

(c) The authorisation granted under these rules shall be valid for a period of five years from the date of its issue.

(d) The Dismantler and Recycler shall maintain records of the e-waste purchased, processed in Form-2 and shall file annual returns of its activities of previous year in Form-3 to the concerned State Pollution Control Board on or before 30th day of June of every year.[1]

\section{PROCEDURE for GRANT of AUTHORISATION to REFURBISHER}

(a) Every refurbisher of e-waste shall make an application in Form 1 (a) in triplicate to the concerned State Pollution Control Board accompanied with a copy of the following documents for the grant of authorisation. [5]

(1) Consent to establish granted by the concerned State Pollution Control Board under the Water (Prevention and Control of Pollution) Act, 1974, (25 of 1974) and the Air (Prevention and Control of Pollution) Act, 1981 (21 of 1981);

(2) Certificate of registration issued by the District Industries Centre or any other government agency authorised in this regard.

(3) Proof of installed capacity of plant and machinery issued by the District Industries Centre or any other government agency authorised in this behalf.

(b) The concerned State Pollution Control Board, on being satisfied that the application is complete in all respects and complies with the guidelines prescribed by Central Pollution Control Board from time to time, may grant one time authorisation in Form 1 (bb) to such applicants stipulating therein necessary conditions as deemed necessary for carrying out refurbishing activities in the authorised place only.[1]

(c) The Refurbisher shall maintain records of the e-waste purchased and refurbished in Form-2 and shall file annual returns of its activities of previous year in Form-3 to the concerned State Pollution Control Board on or before 30th day of June of every year.[1]

\section{RESPONSIBILITIES}

\section{A. RESPONSIBILITIES of the MANUFACTURER}

(a) Collect e-waste generated during the manufacture of any electrical and electronic equipment and channelise it for recycling or disposal. 
(b) ) Apply for an authorisation in Form 1 (a) in accordance with the procedure prescribed under sub-rule (2) of rule 13 from the concerned State Pollution Control Board, which shall give the authorisation in accordance with Form 1 (bb).[1]

(c) Ensure that no damage is caused to the environment during storage and transportation of e-waste.

(d) Maintain records of the e-waste generated, handled and disposed in Form-2 and make such records available for scrutiny by the concerned State Pollution Control Board.

(e) File annual returns in Form-3, to the concerned State Pollution Control Board on or before the 30th day of June following the financial year to which that return relates.[1]

\section{B. RESPONSIBILITIES of the PRODUCER}

The producer of electrical and electronic equipment listed in Schedule I shall be responsible for implementing the Extended Producers Responsibility with the following frameworks.

(a) The mechanism used for channelisation of e-waste from end-of-life products including those from their service centers to authorised dismantler or recycler shall be in accordance with the Extended Producer Responsibility Authorisation. In cases of fluorescent and other mercury containing lamps, where recyclers are not available, channelisation may be from collection centre to Treatment, Storage and Disposal Facility.[1]

(b) Extended Producer Responsibility - Authorisation should comprise of general scheme for collection of waste Electrical and Electronic Equipment from the Electrical and Electronic Equipment placed on the market earlier, such as through dealer, collection centers, Producer Responsibility Organisation, through buy-back arrangement, exchange scheme, Deposit Refund System, etc. whether directly or through any authorised agency and channelising the items so collected to authorised recyclers.

(c) Affixing a visible, legible and indelible symbol on the products or product user documentation to prevent e-waste from being dropped in garbage bins containing waste destined for disposal.

(d) The import of electrical and electronic equipment shall be allowed only to producers having Extended Producer Responsibility authorisation.

(e) Maintaining records in Form-2 of the e-waste handled and make such records available for scrutiny by the Central Pollution Control Board or the concerned State Pollution Control Board.

(f) Filing annual returns in Form-3, to the Central Pollution Control Board on or before the 30th day of June following the financial year to which that return relates. [1]

(g) The Producer shall apply to the Central Pollution Control Board for authorisation in Form 1, which shall thereafter grant the Extended Producer Responsibility - Authorisation in Form 1(aa).[1]

\section{RESPONSIBILITIES of COLLECTION CENTRES}

(a) Collect e-waste on behalf of producer or dismantler or recycler or refurbisher including those arising from orphaned products.

(b) Ensure that no damage is caused to the environment during storage and transportation of e-waste.

(c) Maintain records in Form-2 of the e-waste handled as per the guidelines of Central Pollution Control Board and make such records available for scrutiny by the Central Pollution Control Board or the concerned State Pollution Control Board as and when asked for.[1]

\section{RESPONSIBILITIES of DEALERS}

(a) In the case the dealer has been given the responsibility of collection on behalf of the producer, the dealer shall collect the e-waste by providing the consumer a box, bin or a demarcated area to deposit e-waste, or through take back system and send the e-waste so collected to collection centre or dismantler or recycler as designated by producer.

(b) Every dealer shall ensure that the e-waste thus generated is safely transported to authorised dismantlers or recyclers.

(c) Ensure that no damage is caused to the environment during storage and transportation of e-waste.

\section{E. RESPONSIBILITIES of the REFURBISHER}

(a) Collect e-waste generated during the process of refurbishing and channelise the waste to authorised dismantler or recycler through its collection centre.

(b) Make an application in Form 1(a) in accordance with the procedure laid down in sub-rule (4) of rule 13 to the concerned State Pollution Control Board for grant of one time authorisation [1].

(c) Ensure that the e-waste thus generated is safely transported to authorised collection centres or dismantlers or recyclers.

(d) Maintain records of the e-waste handled in Form-2 and such records should be available for scrutiny by the appropriate authority.

(e) File annual returns in Form-3 to the concerned State Pollution Control Board, on or before the 30th day of June following the financial year to which that return relates.[1] 
Vol. 8, Issue 12, December 2021

DOI: $10.17148 /$ IARJSET.2021.81225

\section{F. RESPONSIBILITIES of CONSUMER or BULK CONSUMER}

(a) consumers or bulk consumers of electrical and electronic equipment listed in Schedule I shall ensure that e-waste generated by them is channelised through collection centre or dealer of authorised producer or dismantler or recycler or through the designated take back service provider of the producer to authorised dismantler or recycler.

(b) Bulk consumers of electrical and electronic equipment listed in Schedule I shall maintain records of e-waste generated by them in Form-2 and make such records available for scrutiny by the concerned State Pollution Control Board.

(c) Bulk consumers of electrical and electronic equipment listed in Schedule I shall file annual returns in Form-3, to the concerned State Pollution Control Board on or before the 30th day of June following the financial year to which that return relates.[1]

\section{G. RESPONSIBILITIES of the DISMANTLER}

(a) Ensure that the facility and dismantling processes are in accordance with the standards or guidelines prescribed by Central Pollution Control Board from time to time.

(b) ) Obtain authorisation from the concerned State Pollution Control Board in accordance with the procedure under sub-rule (3) of rule 13.

(c) Ensure that dismantled e-waste are segregated and sent to the authorised recycling facilities for recovery of materials.

(d) Maintain record of e-waste collected, dismantled and sent to authorised recycler in Form-2 and make such record available for scrutiny by the Central Pollution Control Board or the concerned State Pollution Control Board; [1]

(e) File a return in Form-3, to the concerned State Pollution Control Board as the case may be, on or before 30th day of June following the financial year to which that return relates.[1]

\section{H. RESPONSIBILITIES of the RECYCLER}

(a) Recycler shall ensure that the facility and recycling processes are in accordance with the standards or guidelines prescribed by the Central Pollution Control Board from time to time.

(b) Obtain authorisation from concerned State Pollution Control Board in accordance with the procedure under the subrule (3) of rule 13.[1]

(c) Maintain record of e-waste collected, dismantled, recycled and sent to authorised recycler in Form- 2.

(d) File annual returns in Form-3, to the concerned State Pollution Control Board as the case may be, on or before 30th day of June following the financial year to which that return relates. [1]

\section{CATEGORIES OF ELECTRICAL AND ELECTRONIC EQUIPMENT INCLUDING THEIR COMPONENTS, CONSUMABLES, PARTS AND SPARES COVERED UNDER THE RULES}

\section{A. CATEGORIES of ELECTRICAL and ELECTRONIC EQUIPMENT}

Electrical and electronic equipments are divided in to two categories.[1]

\section{INFORMATION TECHNOLOGY and TELECOMMUNICATION EQUIPMENT:}

(a) Centralised data processing: Mainframes, Minicomputers.( Electrical and electronic equipment code-ITEW1 )

(b) Personal Computing: Personal Computers including Central Processing Unit with input and output devices.

(Electrical and electronic equipment code-ITEW2)

(c) Personal Computing: Laptop Computers including Central Processing Unit with input and output devices.

(Electrical and electronic equipment code-ITEW3)

(d) Personal Computing: Notebook Computers (Electrical and electronic equipment code-ITEW4)

(e) Personal Computing: Notepad Computers (Electrical and electronic equipment code-ITEW5)

(f) Printers including cartridges (Electrical and electronic equipment code-ITEW6)

(g) Copying equipment (Electrical and electronic equipment code-ITEW7)

(h) Electrical and electronic typewriters (Electrical and electronic equipment code-ITEW8)

(i) User terminals and systems (Electrical and electronic equipment code-ITEW9)

(j) Facsimile (Electrical and electronic equipment code-ITEW10)

(k) Telex (Electrical and electronic equipment code-ITEW11)

(l) Telephones (Electrical and electronic equipment code-ITEW12)

(m) Pay telephones (Electrical and electronic equipment code-ITEW13)

(n) Cordless telephones (Electrical and electronic equipment code-ITEW14)

(o) Cellular telephones (Electrical and electronic equipment code-ITEW15)

(p) Answering systems (Electrical and electronic equipment code-ITEW16) 


\section{CONSUMER ELECTRICAL and ELECTRONICS:}

(a) Television sets including sets based on Liquid Crystal Display and Light Emitting Diode technology (Electrical and electronic equipment code-CEEW1)

(b) Refrigerator (Electrical and electronic equipment code-CEEW2)

(c) Washing Machine (Electrical and electronic equipment code-CEEW3)

(d) Air-conditioners excluding centralised air conditioning plants (Electrical and electronic equipment code-CEEW4)

(e) Fluorescent and other Mercury containing lamps (Electrical and electronic equipment code-CEEW5)

\section{PROCEDURE FOR STORAGE OF E-WASTE}

Every Producer, collection centre, dealer, dismantler, recycler and refurbisher may store the e-waste for a period not exceeding one hundred and eighty days and shall maintain a record of collection, sale, transfer and storage of wastes and make these records available for inspection. The period of storage of one hundred and eighty days may be extended by the concerned State Pollution Control Board up to three hundred and sixty-five days in case the waste needs to be specifically stored for development of a process for its recycling or reuse. Storage of end of life products may be done in a manner which does not lead to breakage of these products and safe to workers handling such products. During storage of e-waste care may be taken to avoid damage to refrigerators and air-conditioner so as to prevent release of refrigerant gases and to prevent spillage of oils (mineral or synthetic oil) and other emissions. We have to avoid damage to Cathode Ray Tube, fluorescent and other mercury containing lamps also. Loading, unloading and storage of E-Waste should be carried out in such a way that its end use such as re-use after refurbishing or recycling or recovery is unaffected. The storage area should have fire protection system in place.[1]

\section{TRANSPORTATION OF E-WASTE}

The sender of E-Waste, that may be a producer, manufacturer, recyclers, dismantler, bulk consumer, refurbisher and collection centre should identify transporter or make arrangements for a transporting E-waste in such a manner that environmental consequences of hazards associated with its transport could be kept at minimum. The transportation of e-waste shall be carried out as per the manifest system whereby the transporter shall be required to carry a document (three copies) prepared by the sender, giving the details as per Form-6. The responsibility of safe transportation of Ewaste shall be with the sender of E-Waste. Fluorescent and other mercury containing lamps may be transported to treatment storage and disposal Facility in the cases where no recyclers of CFL are available. The manufacturers and recyclers while transporting waste generated from manufacturing or recycling destined for final disposal to a treatment, storage and disposal facility will follow the provisions under Hazardous and Other Wastes (Management and Transboundary Movement) Rules, 2016.[1,6]

\section{TREATMENT AND DISPOSAL METHODS OF E-WASTE}

Methods for the treatment and disposal of E-waste are as follows.

\section{A. LAND FILLING}

It is widely used methods for disposal of e-waste. In this method, trenches are made on the flat surfaces by removing soil from the trenches and waste material is buried in it, which is covered by a thick layer of soil. Secure landfill is made using modern technique. Here they are provided with some facilities like, impervious liner made up of plastic or clay, leachate collection basin that collects and transfer the leachate to wastewater treatment plant. The degradation processes in landfills are very complicated and run over a wide time span. Land filling method is not considered as a safe method and it is not recommended for the disposal. They may release to the environment after several years by natural means, and there is a possibility of leaching of wastes such as heavy metals, mercury, nickel cadmium, lead, zinc and copper. These may reach the land water and reaches animals and humans, and mixes with other fresh water sources such as rivers and streams.[7]

\section{B. INCINERATION}

In this controlled and complete combustion process, the E- waste material is burned in specially designed incinerators at a high temperature $\left(900-1000^{\circ} \mathrm{C}\right)$. Advantage of incineration of E-waste is the reduction of waste volume and the utilization of the energy content of combustible materials. In this method some environmentally hazardous organic substances are converted into less hazardous compounds. Incineration is a commonly used method of the disposal of ewaste.[3]

\section{RECYCLING of E-WASTE}

Fridge, Washing machines, TVs, Monitors \& CRT, keyboards, laptops, modems, telephones, hard drives, floppy drives, Compact disks, mobiles, fax machines, printers, CPUs, memory chips, connecting wires \& cables can be recycled. 


\section{DOI: 10.17148/IARJSET.2021.81225}

Recycling involves dismantling i.e. removal of different parts of e-waste containing dangerous substances like PCB, $\mathrm{Hg}$, separation of plastic, removal of CRT, segregation of ferrous and nonferrous metals and printed circuit boards. Strong acids are used to remove precious metals such as copper, gold, palladium. The value of recycling from the element could be much higher if appropriate technologies are used.[2,7]

\section{ACCIDENT REPORTING}

Where an accident occurs at the facility processing e-waste or during transportation of e-waste, the producer, refurbisher, transporter, dismantler, or recycler, as the case may be, shall report immediately to the concerned State Pollution Control Board about the accident through telephone and e-mail.[1]

\section{LIABILITY OF MANUFACTURER, PRODUCER, IMPORTER,TRANSPORTER,REFURBISHER, DISMANTLER AND RECYCLER}

(a) The manufacturer, producer, importer, transporter, refurbisher, dismantler and recycler shall be liable for all damages caused to the environment or third party due to improper handling and management of the e-waste.[1]

(b) The manufacturer, producer, importer, transporter, refurbisher, dismantler and recycler shall be liable to pay financial penalties as levied under the Provisions of the Environment (Protection) Act, 1986 and rules made there under for any violation of the provisions under these rules by the State Pollution Control Boards with the prior approval of the Central Pollution Control Board in accordance with the guidelines published by the Central Pollution Control Board.[5]

\section{CONCLUSION}

The hazardous nature of e-waste is one of the rapidly growing environmental problems of the world. In this study, the focus was on the management of e-waste disposal. We have discussed the functional elements involved in e- waste management (i.e. procedure of authorization, responsibilities, e-waste categories,. procedure for storage, transportation, treatment, disposal, accident reporting and liability). Subsequently we explained the methods of e-wastes disposal through land filling, incineration and recycling to reduce their impact on public health and the environment. The result of the study demonstrate the need for strict enforcement of legal provisions and a better environment system for the disposal of e-waste. Provision of a e-waste management planning and monitoring system is a prerequisite issue for effective reduction of e-waste associated risks.

\section{REFERENES}

[1]. Gazette of India. GSR. 338(E) dated 23 March 2016, E-Waste (Management) Rules, 2016, Ministry of Environment, Forests and Climate Change, Government of India, New Delhi, India. 2016, 1-42.

[2]. M.C.Vats, S.K.Singh. E-Waste Characteristic and its Disposal. International Journal of Ecological Science and Environmental Engineering. Vol.1, No.2, 2014, pp. 49-61

[3]. Sivakumaran Sivaramanan. E-Waste Management, Disposal and Its Impacts on the Environment. Universal Journal of Environmental Research and Technology. 2013 Volume 3, Issue 5: 531-537

[4] Andeobu, L., Wibowo, S.; Grandhi, S. A Systematic Review of E-Waste Generation and Environmental Management of Asia Pacific Countries. Int. J. Environ. Res. Public Health 2021, 18, 9051.

[5]. Gazette of India. GSR. 261(E) dated 22 March 2018, E- Waste (Management) Amendment Rules, 2018, Ministry of Environment, Forests and Climate Change, Government of India, New Delhi, India. 2018.

[6 ] Gazette of India. GSR. 395(E) dated 4 April 2016, The Hazardous and Other Wastes (Management and Transboundary Movement) Rules, 2016., Ministry of Environment, Forests and Climate Change, Government of India, New Delhi, India. 2016, 1-20.

[7]. G.Gaidajis, K. Angclakoglou and D.Aktsoglon. E-Waste: Environmental problems and current Management. Journal of Engineering Science and Technology Review, 3(1) (2010) 193-199 